
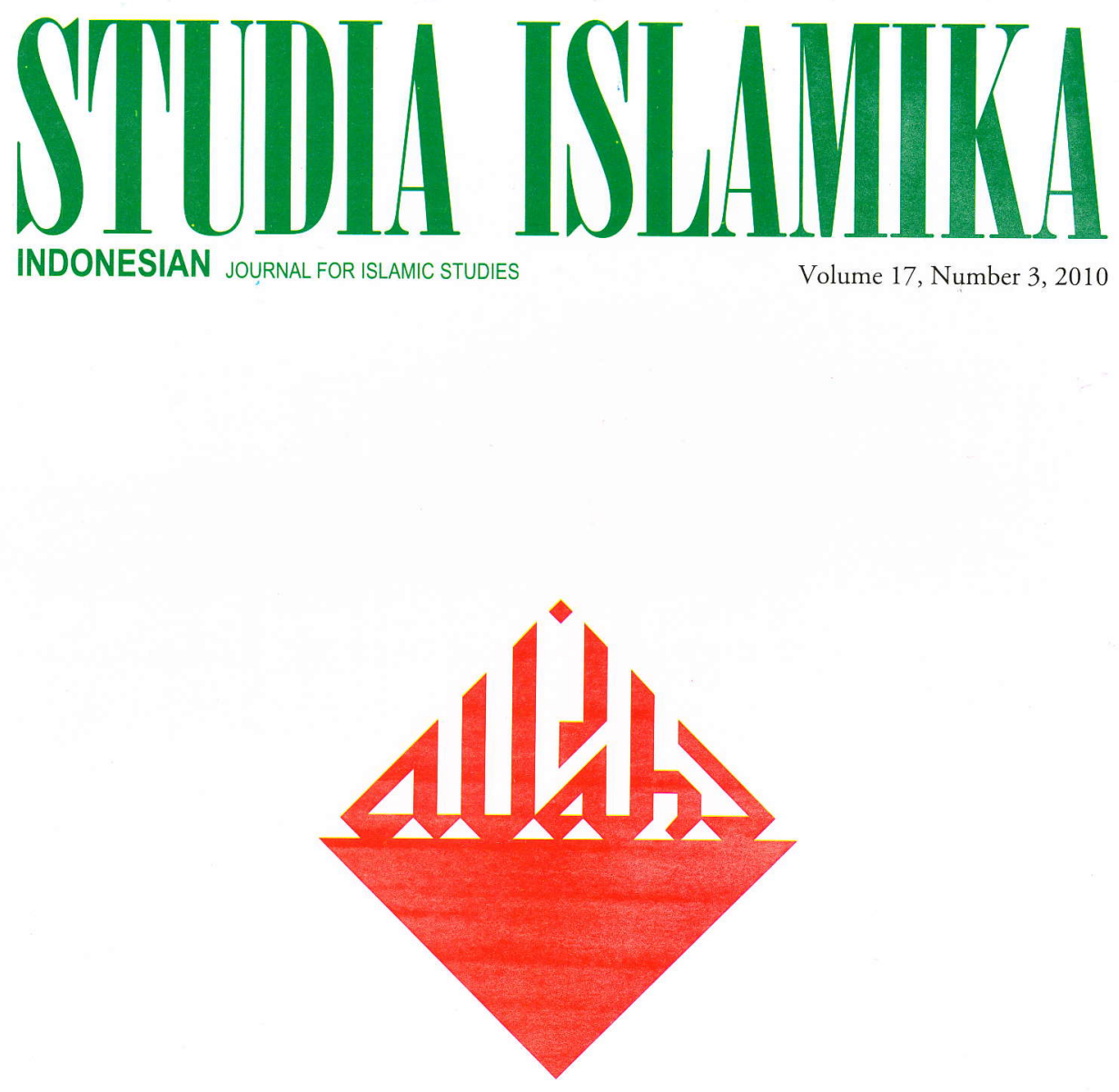

THE ELITIST PREMISES OF

SnOUCK Hurgonje'S Association Fantasy

Kees van Dijk

The Shaving of The Prophet's Hair (NABI APARAS):

The Philology of Lombok TeXts

Dick van der Meij

RELIGION AND DIALOGUE IN INDONESIA:

From the SOEHARTO PERIOD TO THE PRESENT

Mujiburrahman 


\section{EDITORIAL BOARD:}

M. Quraish Shihab (UIN Jakarta)

Taufik Abdullah (LIPI Jakarta)

Nur A. Fadhil Lubis (IAIN Sumatra Utara)

M.C. Ricklefs (National University of Singapore)

Martin van Bruinessen (Utrecht University)

John R. Bowen (Washington University, St. Louis)

M. Atho Mudzhar (UIN Jakarta)

M. Kamal Hasan (International Islamic University, Kuala Lumpur)

M. Bary Hooker (Australian National University, Australia)

Virginia Matheson Hooker (Australian National University, Australia)

\section{EDITOR-IN-CHIEF}

Azpumardi Azra

\section{EDITORS}

Jajat Burbanudin

Saiful Mujani

Jambari

Fu'ad Jabali

Oman Fathurabman

\section{ASSISTANT TO THE EDITORS}

\section{Testriono}

Setyadi Sulaiman

\section{ENGLISH LANGUAGE ADVISOR}

Dina Afrianty

Dick van der Meij

\section{ARABIC LANGUAGE ADVISOR}

Abmadi Rojali

\section{COVER DESIGNER}

\section{S. Prinka}

STUDIA ISLAMIKA (ISSN 0215-0492) is a journal published by the Center for the Study of Islam and Society (PPIM) UIN Syarif Hidayatullah, Jakarta (STT DEPPEN No. 129/SKIDITJEN/PPG/STT/1976). It specializes in Indonesian Islamic studies in particular, and South-east Asian Islamic Studies in general, and is intended to communicate original researches and current issues on the subject. This journal warmly welcomes contributions from scholars of related disciplines.

All articles published do not necessarily represent the views of the journal, or other institutions to which it is affliated. They are solely the views of the authors. The articles contained in this journal have been refereed by the Board of Editors. 
Kees van Dijk

\title{
The Elitist Premises of Snouck Hurgronje's Association Fantasy
}

\begin{abstract}
Abstrak: Perumusan kebijakan kolonial Snouck Hurgronje (1857-1936) memperlihatkan sejumlah kontradiksi. Salah satu contoh ambiguitas tersebut adalah perannya dalam Perang Aceh. Menurut Hurgronje, cara-cara militer perlu digunakan kepada musuh yang menentang pemerintah dan tidak boleh diberiampun. Pembelaan Hurgronje atas penggunaan pendekatan militeristik tersebut terjadi seiring dengan kebijakannya untuk menggunakan cara-cara damai. Kontradiksi lainnya, meski mengakui peran tokoh agama dalam barisan depan penentang ekspansi Belanda, Hurgronje menolak mengakui peran agama dalam Perang Aceh itu. Artikel ini memperlihatkan ambiguitas-ambiguitas kebijakan kolonial Snouck Hurgronje tersebut.

Salah satu gagasan Snouck Hurgronje yang paling terkenal adalah kebijakan asosiasi (association policy). Melalui kebijakan ini mayoritas penduduk lokal harus berasimilasi dengan budaya minoritas lain yang kecil, yaitu budaya masyarakat Eropa di Hindia Belanda. Kebijakan ini berorientasi pada terciptanya inkorporasi spiritual'- terpisah jauh secara geografis, namun terhubung dekat secara batin — bagi jutaan penduduk asli, yang sampai pada masa Snouck Hurgronje hanya berhasil dikuasai Pemerintah Belanda dalam pengertian administratif. Menurutnya, kesatuan budaya akan menghapus perbedaan agama antara orang-orang Belanda dan Indonesia secara politik dan sosial.

Pendekatan kebijakan kolonial Hurgronje didasarkan pada dua asumsi. Pertama terkait dengan superioritas peradaban Barat, kedua terkait dengan pendekatan Barat yang minimal kepada Islam. Dengan kebijakan asosiasi tersebut Hurgronje menentang setiap praktik diskriminasi dan mendukung penghapusan perbedaan di hadapan hukum bagi orang Eropa dan pribumi. Bagi Hurgronje, emansipasi harus dimulai dari lapisan masyarakat atas. Pendidikan adalahsentral dalam konsepasosiasi tersebut. Anak-anak Indonesia yang berbakat harus menerima baik pendidikan dasar maupun lanjutan untuk menyiapkan mereka menjadi pejabat pemerintah.
\end{abstract}

407 Studia Islamika, Vol. 17, No. 3, 2010 
Dalam kaitan ini, Hurgronje memberikan perhatian khususpada anak-anak para priyayi, elite administratif dan politik Indonesia di Jawa. Achmad Djajadiningrat adalah eksperimen awalnya. Dia direkrut oleh Snouck Hurgronje pada 1890 dan disekolahkan di sekolah Belanda ketika masih berumur 13 tahun. Snouck Hurgronje memberi bantuan mulai dari pemilihan sekolah sampai pencarian asrama. Hasil eksperimen awal Hurgronje tersebut terlihat nyata: Achmad Djajadiningrat (18771943) diangkat menjadi Bupati Serang pada 1901. Contoh elite pribumi lain yang merupakan hasil dari kebijakan Hurgronje adalah Koeseoemo Oetojo yang menjadi Bupati Ngawi pada 1902-1905, kemudian Jepara sampai 1920, dan Wiranatakoesoema yang menjadi Bupati Cianjur pada 1912 dan Bandung pada 1920.

Namun, Snouck Hurgronje agaknya tidak sadar dengan perkembangan baru munculnya sekolah-sekolah Islam modern. Madrasah Manba'ul Ulum adalah sekolah Islam modern yang didirikan pada Juli 1905, setahun sebelum kepulangannya ke Belanda, atas inisiatif Susuhunan Pakubuwono X dari Surakarta dan peran penghulu, elite muslim yang telah terinkorporasi dengan budaya kolonial. Sekolah modern model madrasah yang mengadopsi sistem kelas dan pelajaran umum selain agama ini kemudian didirikan di banyak tempat hingga ke dalam pesantren. Snouck Hurgronje tidak memberikan perhatian atas munculnya tren baru tersebut. Sebab, dia tidak beranggapan bahwa Islam dapat menjadi rintangan di Hindia Belanda daripada di Timur Tengah. Baginya pengaruh Islam sangat kecil dalam kehidupan masyarakat Jawa akibat kontak orang Jawa pada masa lalu dengan berbagai budaya lain. Selain itu, dalam pengamatan Snouck Hurgronje, orang-orang Jawa taat terhadap pemimpin mereka dan para pemimpin tersebut man mengikuti arahan pejabat Belanda.

Dengan demikian, kelompok masyarakat yang ada dalam pikiran Snouck Hurgronje sesungguhnya adalah elite Jawa, dan mimpinya adalah terciptanya muslim yang terbaratkan. Untuk mewujudkannya, strategi yang harus ditempuh adalah membuat anak-anak elite Jawa kebal terhadap dakwah kelompok yang dia sebut pemimpin Islam berpikiran sempit, melalui pendidikan sekular Eropa dengan para gurunya merupakan orang-orang Eropa. Jenis pendidikan ini akan menciptakan elite Indonesia baru yang berakar pada elite sekular tradisional. Akan tetapi, kebijakan pendidikan tersebut justru membuka jalan bagi munculnya gerakan nasionalis awal. Dan yang pasti, gagasan memberikan pendidikan bagi anak-anak kaum priyayi menunjukkan sikap Snouck Hurgronje yang diskriminatif; suatu kontradiksi dalam kebijakan emansipasinya. 


\section{Kees van Dijk}

\section{The Elitist Premises of Snouck Hurgronje's Association Fantasy}

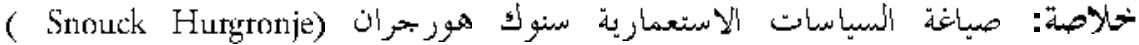
( AOV)

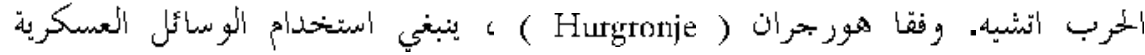

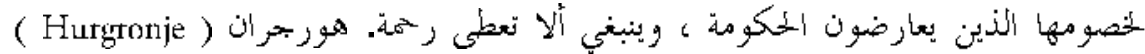

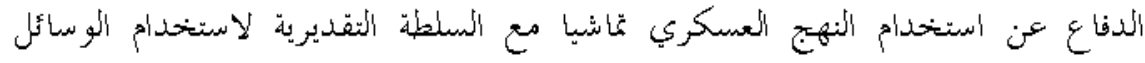

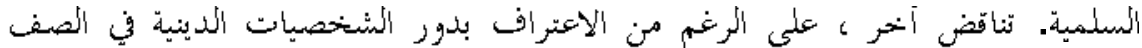

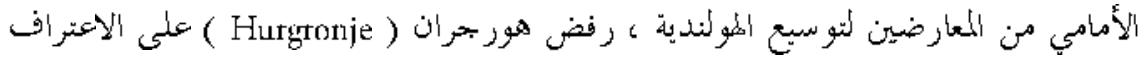

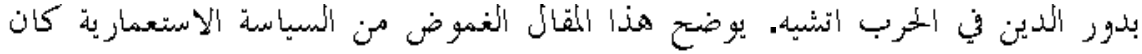

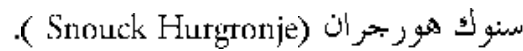

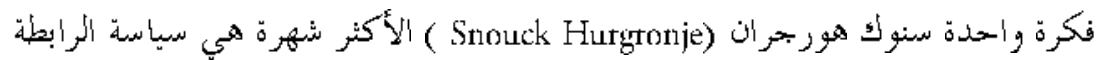

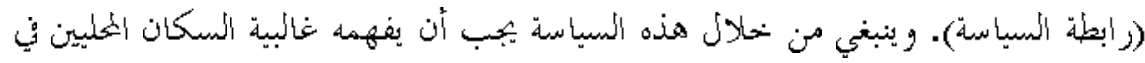

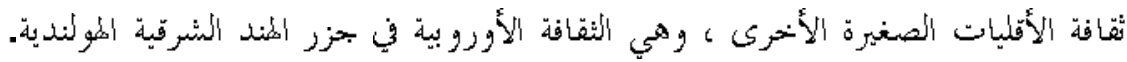

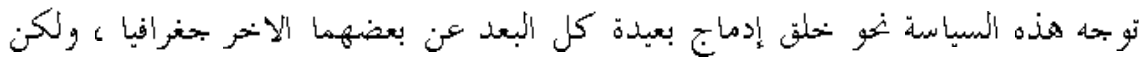

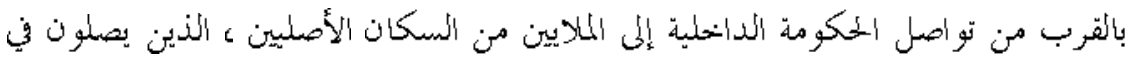

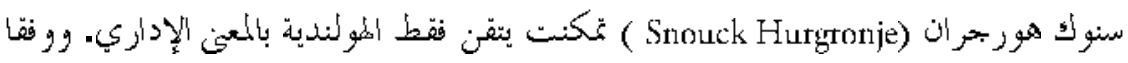

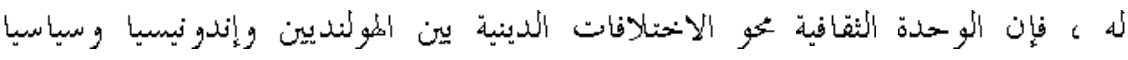
ا'بحتمانعيا. 


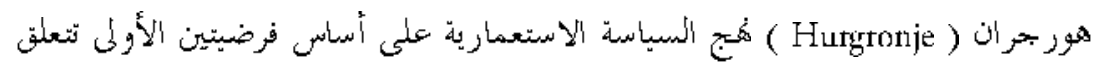

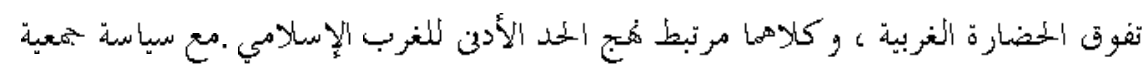

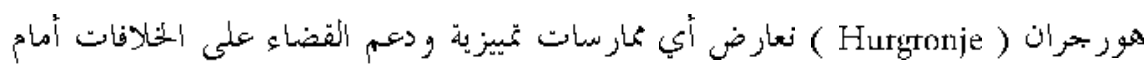

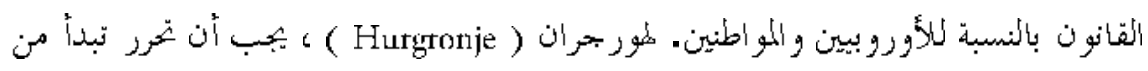

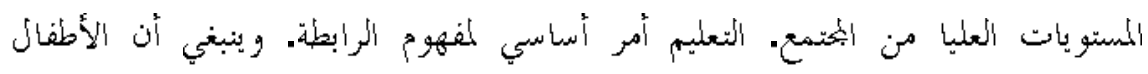

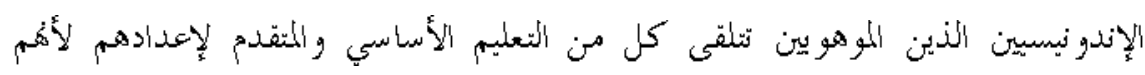

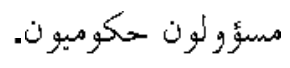

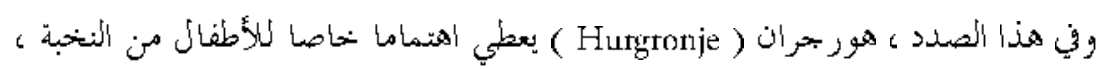

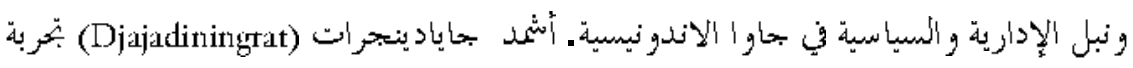

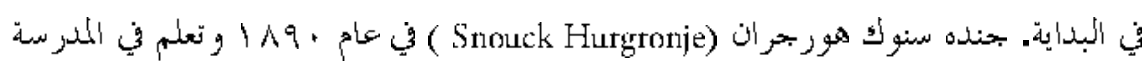

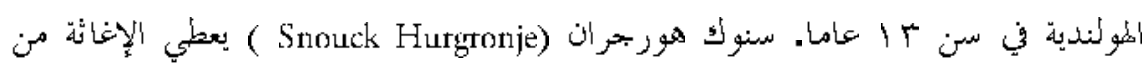

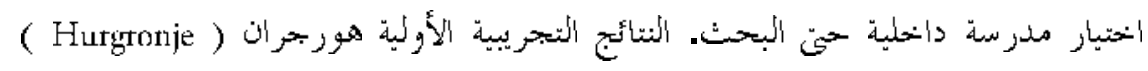

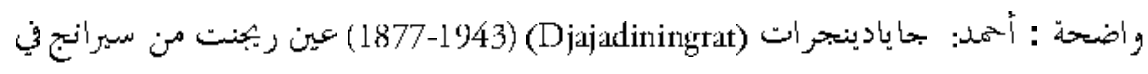

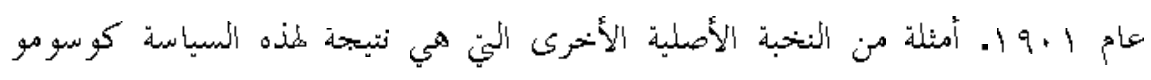

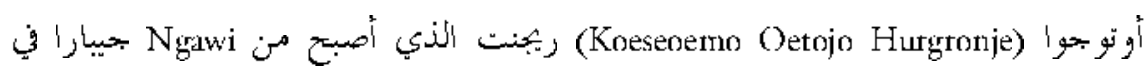

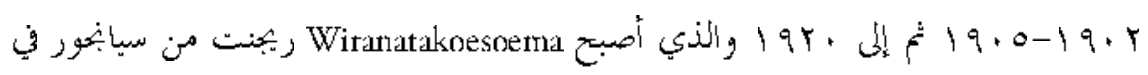
$.19 \%$.

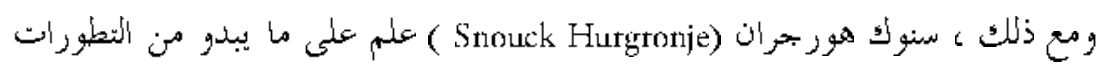

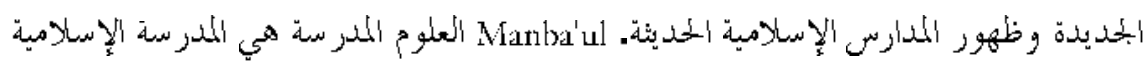

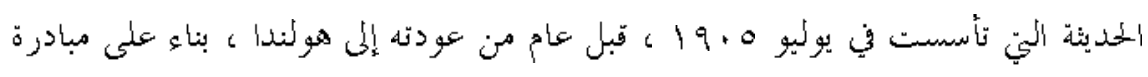

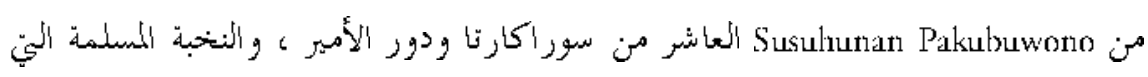

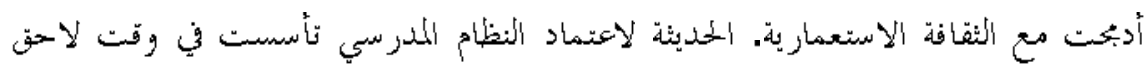

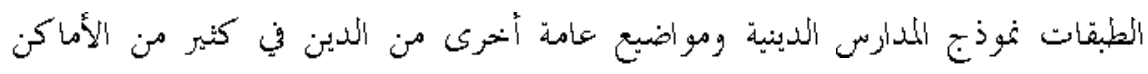

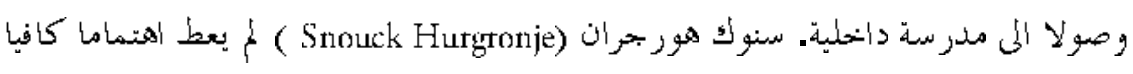

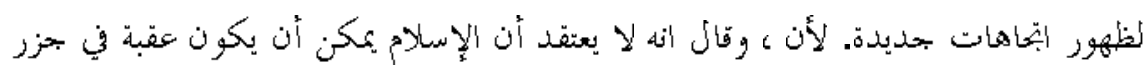

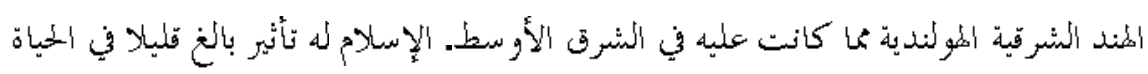




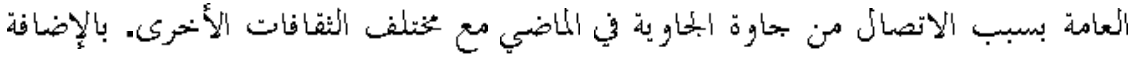

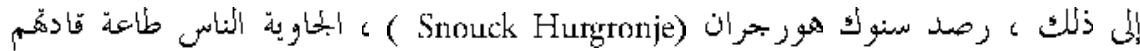

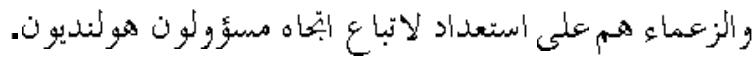

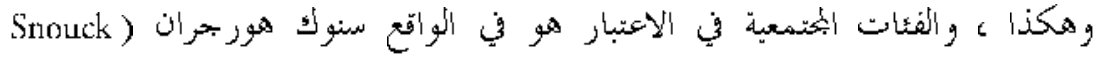
( Hutgtonje

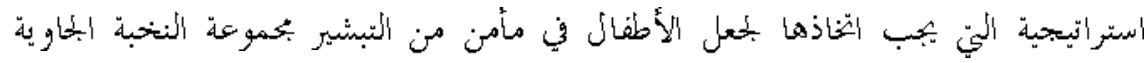

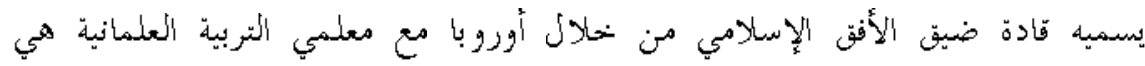

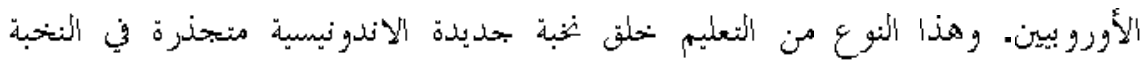

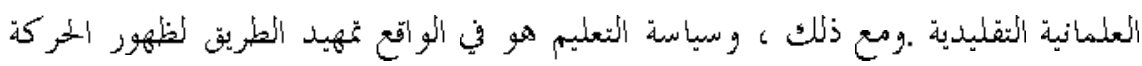

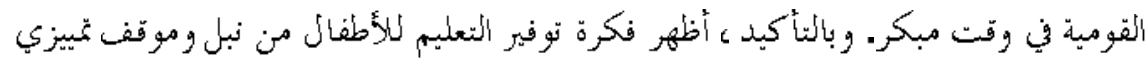

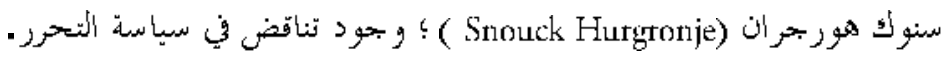



Kees van Dijk

The Elitist Premises of Snouck Hurgronje's Association Fantasy

$\mathrm{R}$

ight from his initial involvement in formulating colonial policy, Snouck Hurgronje (1857-1936) appears to have been a bundle of contradictions. One example of such ambiguity is his role in the Aceh War. It provides us with a classic example of the paradoxes inherent in a war of expansion. Driven by fierce patriotic sentiments Snouck Hurgronje adopted the position of a war-monger, urging earlier than any of his civilian and military contemporaries did that an aggressive war of conquest be waged in which the enemy should be given no quarter. $\mathrm{He}$ acknowledged that religious leaders were in the forefront of the resistance against the expansion of Dutch rule and was fully aware that the call to fight the infidel enemy was one of their chief assets. Nevertheless he curiously seems to deny the role of religion. His pleas to hammer the enemy hard and relentlessly were made alongside appeals for moderation in the use of force. The reasons he gave for the latter was that excessive violence might alienate the Acehnese population, which might otherwise be won over by the twin virtues of economic development and the spread of Western civilization. It does not seem to have entered his head that ordinary Acehnese might not take the merciless hounding of their religious leaders lightly or that they might continue to identify the Dutch with loathed infidels and all the consequences of this. If it did it was very much in second place.

Snouck Hurgronje was earnest in his pleas that priority should be given to the promotion of the local economy, and reacted with venom to anything which distracted from this, especially when money that could have been spent to benefit Acehnese society was used to further 
the interests of the local European community. As a person not inclined to compromise or indeed to considering the possibility that he had made a mistake, his insistence on this point meant the end of his career in the Netherlands Indies. His misfortune was that the person with whom he quarrelled in 1902 and 1903 was his military counterpart in the effort to conquer Aceh, J.B. Van Heutsz, then Civil and Military Governor of Aceh. Initially their dissension only meant the end of Snouck Hurgronje's involvement with Aceh, where he had spent a pleasant and exciting time. Snouck Hurgronje, then in his early forties, had loved joining the troops in their campaigns: 'More appetite, better digestion, cheerfulness, etc.', he wrote to his teacher and friend Nöldeke, when reporting about his Aceh adventures. (SH to N 25-6-1898, Van Koningsveld 1985b:64). His pride hurt Snouck Hurgronje refused to have anything any longer to do with Aceh. He never visited Aceh again and an end came to his recommendations how to proceed in Aceh. After Van Heutsz had become Governor-General of the Netherlands Indies in 1904, the consequences were even more far-reaching. Side-tracked and now rarely asked to submit recommendations to the colonial government, Snouck Hurgronje left the Netherlands Indies for Holland in March 1906, never to return to the colony again, though initially at least he yearned to return.

\section{The association policy}

His approach to Aceh was inspired by the very clear picture Snouck Hurgronje had in his mind of the future of the Netherlands Indies. He explained his vision in one of the lectures he gave in 1911 at the NetherlandsIndies Civil Servants College (Nederlandsch-Indische Bestuursacademie) in The Hague. There he impressed upon his audience that the 'only real solution' to the Islam question was 'the association of the Mohammedan subjects of the Dutch state with the Dutch' (Snouck Hurgronje 1915:83). Once this was accomplished, there would no longer be any Islam problem. The result would be 'sufficient unity of culture between the subjects of the Queen of the Netherlands along the shores of the North Sea and those of Insulinde to eradicate the political and social significance of the difference in religious profession' (Snouck Hurgronje 1915:83). Snouck Hurgronje evoked 'a beautiful political and national idea, which is the genesis of a Dutch state consisting of two parts, geographically far apart but spiritually intimately linked, the one in North-West Europe, the other in South-East 
Asia' (Snouck Hurgronje 1915:85). His emphasis on becoming 'spiritually intimately linked' intimates that, in Snouck Hurgronje's view, intellectual development may have been even more important that material progress.

What he did not say, but what he seems to have had in mind, was the winning over of the local elite, on the assumption that after this had been accomplished the rest of the population would follow automatically. In his conviction of the ultimate truth of this concept, Snouck Hurgronje could embark on his Aceh policy. At some point in future the Acehnese would also gladly accept Dutch rule, provided that the Dutch strained every sinew not to offend them and made an honest effort to develop the local economy. He thought that the promotion of trade by the Acehnese would be a key factor in bringing prosperity to the region. Snouck Hurgronje admitted that Acehnese acceptation of Dutch rule could take decades, but in the long run what he envisaged would be a reached. In present-day terminology: at a certain point in future the Dutch would win the hearts and minds of the Acehnese.

When we take a closer look at what has become known as the 'association policy' or 'association idea' Snouck Hurgronje formulated than the inevitable conclusion has to be that what he envisaged is in fact very peculiar. Nowadays in the Netherlands there is a lot of talk about association, about the integration of immigrants from outside Europe into European society. The essence of such discussions is the demands that a minority of immigrants and their descendents has to adjust to the norms and values of the autochthonous majority. In Snouck Hurgronje's concept it is the other way round. It seems to imply that a huge domestic majority had to assimilate to the culture of a tiny alien minority. In a greatly inflated interpretation of what Snock Hurgronje had in mind, one of his admirers, Calcar (1936:23), wrote that Snouck Hurgronje strove for 'the spiritual incorporation' of millions of natives, who up to that moment only belonged to the Netherlands in the administrative sense. Whether this was indeed Snouck Hurgronje's intention is debatable, as his efforts were aimed at a tiny minority of the Indonesian population, the indigenous administrative elite.

Snouck Hurgronje's approach was based on two assumptions. One concerned the superiority of Western civilization, the other testified to a very Western approach to Islam. To his credit it should be mentioned that Snouck Hurgronje was against any discrimination and advocated the disappearance of the difference before the law of Europeans and Natives. 
Emancipation should begin in the upper layers of society. Education was central to this concept. Talented Indonesian boys should receive a thorough Western primary and secondary education to prepare them for their service in the Indonesian bureaucracy.

Nevertheless, there was a price to be paid. There was more at stake than education (onderwijs). What counted was 'formation and training' (vorming en opvoeding) (SH to R 8-9-1904, Gobée and Adriaanse 19571965:544). Snouck Hurgronje's ideas about the assimilation of the Indonesians meant that they had to conform to Western culture and also implied an estrangement from their own Indonesian civilization and the acceptance a specific interpretation of the concept of religion. Promising sons of the traditional Indonesian ruling elite should leave their own environment and be transported to a literally purely European one. $\mathrm{He}$ wanted, and he claimed that the parents also preferred this, the families with whom the boys were to lodge were those of white Europeans ( $\mathrm{SH}$ to R 8-9-1904, Gobée and Adriaanse 1957-1965:544). The Indo-European milieu, to which he from time to time derogatory referred to by placing the word Europeans between quotation marks, or called 'Europeans according to the law' and 'so-called Europeans', Snouck Hurgronje considered would be invidious to the mental development of the boys as his indictment reveals: 'Actually among them many are indolent, for the job of upbringing unsuited Native mothers. They are usually on a much lower level than the wives of the higher Native civil servants, or half European [mothers] whose culture equals that of the lower Native women, and fathers who do not devote the rare spare hours they have to the forming of their sons, and also would not be able to do so' (SH to R 8-9-1904, Gobée and Adriaanse 1957-1965:543).

Snouck Hurgronje's approach is reminiscent of the way a century earlier the British India Company had 'sanitized' British boys who were preparing for a career in the colonial civil service. It had done so partly by closing the College of Fort William in Calcutta, set up in 1800 by the then Governor-General, the Marquess Wellesley. At the college, teenagers who had entered the service of the East India Company were given a thorough, high quality education in the cultures and languages of the Subcontinent, exposing them also to Indian civilization. To shield the young men from such influences, Haileybury College was founded in the motherland in 1806 and thereafter future civil servants had to study there first for two years before they were sent to India to enroll at Fort William College (or 
similar establishments in Madras and Bombay). In the Netherlands Indies this sort of isolation of Indonesian boys who were selected for a European education at what was considered to be an impressionable age was an impossibility. They met Indonesians in the street and when they returned home during the holidays. At school they also met Indo-Europeans, who in fact made up a significant number of their classmates. In the autobiography of one of the Indonesians concerned, Achmad Djajadiningrat (1936:78), one of the sub-headings speaks of 'bad friends', which in the first instance meant an Indo-European fellow secondary school student who would later be sentenced to death for murder.

\section{Educating the sons of the elite}

In Snouck Hurgronje's view, a new educational path should be pioneered to train future senior members of the native civil service. He had a low opinion of the existing Training School for Native Civil Servants (OSVIA, Opleidingsschool voor Inlandsche Ambtenaren), the continuation of the Hoofden School (Chiefs' School) which prepared its students for a position in it. The real reason was probably precisely because the students in these boarding schools were not shielded from Indonesian society or, as Achmad Djajadiningrat (1936:67), writing about a brief visit to one of these schools in Bandung in the early 1880s, indicated were not allowed to enter the European world by their headmaster. Snouck Hurgronje considered the standard of OSVIA unfit to produce capable Indonesian civil servants. Writing about the same school in Bandung which Achmad Djajadiningrat had visited he deplored the lack of supervision of 'education in the widest sense of the word,' which was what counted in his mind (SH to DCA 17-8-1905, Gobée and Adriaanse 1957-1965:532). Consequently, he was adamant that promising young Indonesian men who opted for a career in the Indonesian civil service - or were hand-picked by Europeans to be prepared for such a career - should enroll at European primary and secondary education institutions, the Europeesche Lagere School and the Hoogereburgerschool (HBS) and the Gymnasium, which when Snouck Hurgronje commenced putting his ideas into practice did not yet accept Indonesians as pupils.

Snouck Hurgronje turned to the sons of the priyayi, the local Indonesian political and administrative elite in Java, for what can be described as his project; he himself uses the terms experiments and 
testing (proefnemingen, proeven), a kind of endeavour for which colonial societies provided such a suitable environment. ${ }^{1}$ To set his sights on the local Javanese nobility, the priyayi, was a logical choice, but it also tallied with the political views of Snouck Hurgronje. He abhorred social democrats. The 'feudal set-up' in the colony had made it easier for him to leave 'socially democratic Europe and assuaged homesickness,' he wrote to Nöldeke in 1893 (SH to N 4-6-1893, Van Koningsveld 1985b:36). If such boys received a Western upbringing, this would make all the difference. In practice this meant that a boy considered bright enough to undertake European education would leave home when he was seven or eight years of age (it was impossible to begin too early, Snouck Hurgronje wrote to Rooseboom) and would have to live with a European family until he had completed his secondary education. (SH to R 8-9-1904, Gobée and Adriaanse 1957-1965: 545,551, SH to VH 19-2-1905, Gobée and Adriaanse 1957-1965:555). A revealing, but probably extreme example of the extent to which these young men could become estranged from their own society is provided by what Snouck Hurgronje tells us about a certain 'N'. This lad who left home when he was eight years old had 'lived for fourteen years in a such a purely European circle that he had completely forgotten his mother tongue, when he went to Leiden to take up a study' (SH to VH 19-2-1905, Gobée and Adriaanse 1957-1965:555). ${ }^{2}$

It takes little imagination to realize that the ideas of Snouck Hurgronje did not go down well in contemporary colonial society. In 1889 when Snouck Hurgronje arrived in the Netherlands Indies the idea that Indonesians would be allowed to enroll in European schools was still unheard of. Nevertheless, there were other Europeans who shared Snouck Hurgronje's conviction that Indonesians should receive a European upbringing. Snouck Hurgronje was not the only Dutch civil servant, indeed not the first, who took the cause of a Western education for sons of the Indonesian elite at heart, in the sense of the opening up of European schools, but he certainly was the most influential of them. Admission of Indonesians to such schools was the first obstacle to be overcome. Removing the hostility to Westerneducated Indonesian civil servants among Indonesian and European administrators was a second hurdle. In retrospect Snouck Hurgronje complained that more than once the attitude of European civil servants had made him dissuade Indonesians from enrolling at European secondary schools. Had they succeeded, 'bitter, hurtful disappointments' could befall them as they had to embark upon a career demanding little knowledge and 
'complete servility' (SH to VH 19-8-1905, Gobée and Adriaanse 19571965:557). Such European civil servants would, for instance, demand to be addressed in the 'Volapük [artificial] Malay' (and not in Dutch, the language Indonesians who had completed European secondary education spoke fluently) (Snouck Hurgronje 1908:165).

Initially he and the others who shared his view had to convince the European community of the benefits of idea. The Indonesian aristocracy was also reluctant to acquiesce in it. As one of the major reasons for their attitude, Van Niel (1984:47) thinks that its members feared the loss of their children's social standing. Cultural opposition also loomed on the horizon. When a European-educated man entered the native civil service, he ran the risk of being berated by his superiors for the way he dressed and behaved. Opposition was also still fuelled by religious sentiments, certainly the feelings harboured by the religious conservative Muslims, rejecting any form of Westernization, but also present in wider Muslim society.

\section{The first experiment}

Snouck Hurgronje must have thought about the education of the sons of priyayi even before he left for the Netherlands Indies. It is also not possible to preclude the assumption that he had discussed the topic with members of Indonesian community in Jeddah and Mecca. In 1884-1885, during the time he spent in the Arabian Peninsula, he had met Raden Aboe Bakar Djajadiningrat (c.1854-c.1914), the dragoman, translator, of the Dutch consulate in Jeddah. The two developed a close relationship. Snouck Hurgronje moved in with Aboe Bakar Djajadiningrat, who would become first his teacher and later one of his most trusted sources about Islam and developments in the Islamic communities in the Netherlands Indies and the Middle East (Laffan 2003:52,62). Shortly after his arrival in the Netherlands Indies in 1889, he would turn to Raden Bagus Djajawinata (1854-1899), Regent (Bupati) of Serang from 1894 to 1899, Aboe Bakar Djajadiningrat's elder brother, in Banten, West Java, and take charge of the education of his sons Achmad, Hoesein ${ }^{3}$ and Hasan Djajadiningrat. All three would attend the HBS. Of them, Achmad, was the very first Indonesian boy to come under the tutelage of Snouck Hurgronje. He was his 'initial experiment' (eerste proefneming), as Achmad Djajadiningrat (1936:69) himself wrote; copying the terminology of his mentor. Snouck Hurgronje took him under his wing in 1890 , when he was about thirteen years of age. 
Raden Bagus Djajawinata was receptive to the idea of his sons enjoying a European education. From Achmad Djajadiningrat's autobiography we know that, at the suggestion of his uncle, Raden Adipati Soetadiningrat, then Regent of Pandeglang, and afterwards Regent of Serang (1888?1893), he had to terminate his pesantren education and enrol in a school for sons of Indonesian heads to founded in Pandeglang by Soetadiningrat, where he would be taught Dutch among other subjects (Djajadiningrat 1936:24).

The school and the idea of giving the children in his family a Western education was Soetadiningrat's own idea. Presaging what Snouck Hurgronje would often complain about, local Dutch civil servants did not give him any support nor did they show any appreciation for his initiative (Djajadiningrat 1936:27). After Soetadiningrat had become regent of Serang, he arranged for Achmad Djajadiningrat to be placed in the house of A.J.N. Engelenberg, a Dutch civil servant stationed in Cilegon, who would teach him Dutch and arithmetic (and cautioned him not to mingle too frequently with young magang, Indonesian clerks) (Djajadiningrat 1936:60). In Cilegon Achmad Djajadiningrat met Snouck Hurgronje for the first time, a 'man to whom my whole family owes much and who had the greatest influence on my realm of thought and aspirations until the end of my career' (Djajadiningrat 1936:62).

Shortly after meeting Snouck Hurgronje, Achmad Djajadiningrat was told that he would have to move to Batavia. There he lodged with the Kampschuur family and was given to understand that he had to visit Snouck Hurgronje every Sunday. He began at the European Primary School where Kampschuur, a 'pure-bred Dutchman', was a teacher. When the Kampschuur family went to Europe on leave/furlough, Achmad Djajadiningrat who by now dressed as a European and, as Snouck Hurgronje (1908:162) observed, whose Dutch was better than that of most of the offspring of Europeans born in the Netherlands Indies, found new lodgings. He also changed school. Initially the headmaster of the new school, D.M. Kruseman, was hostile to the idea. He feared that having an Indonesian boy in the class would lower the standard of teaching. Snouck Hurgronje succeeded in convincing him that he was wrong, but there was still one obstacle to overcome. Kruseman remained anxious about the image of his school if an Indonesian should enrol. 'Well-to-do families' might steer clear of the school when it became known that it had an Indonesian boy among its pupils. Consequently, Achmad Djajadiningrat 
was forced to change his name to Willem van Bantam (William of Bantam). It made him a European and, as he wrote, protected him from teasing by the other pupils who did not realize that he was a Sundanese. Achmad Djajadiningrat succeeded in impressing Kruseman, who as it transpired was to support Achmad Djajadiningrat's education to the hilt, suggesting that he should go to the HBS and for which he taught him French in preparation for this step. (Djajadiningrat 1936:66-8, Snouck Hurgronje 1908:162).

In 1893 Achmad Djajadiningrat went to the HBS in Batavia. Because he had to register formally, he again became Achmad, at least at school, but not in his lodging house (Djajadiningrat 1936:75). The consequences were unpleasant. His former male and female friends began to shun him.

Snouck Hurgronje was proud of Achmad Djajadiningrat's achievement. He wrote to both Nöldeke and his Hungarian friend and fellow Islam scholar, Ignaz Goldziher, that he was supervising the education of the fifteen-year-old son of a Javanese civil servant and that the boy always topped his class at a school attended only by Dutch pupils (passing over the Indo-European pupils in silence) and that he had passed his entrance examination for the Gymnasium as number two out of 107 children (SH to N 4-6- 1893, Van Koningsveld 1985b: 35, SH to G 1-6-1893, Van Koningsveld 1985a:140).

In a sense the stakes were high. Later in life Achmad Djajadiningrat gave the impression that to overcome initial opposition in priyayi circles, including in his own wider family, Snouck Hurgronje needed a concrete success (Djajadiningrat 1927:66, Snouck Hurgronje 1908:162-3). Achmad Djajadiningrat provided this. It made fathers who had at first fiercely opposed the European education of priyayi children change their minds and contact Snouck Hurgronje to ask him to arrange the education of their sons. There were so many, Snouck Hurgronje wrote, that he had trouble finding the time to comply with the requests (Snouck Hurgronje 1908:163).

The results of Snouck Hurgronje's initial experiment are now public knowledge. Achmad Djajadiningrat (1877-1943) was appointed Regent of Serang in 1901. He was 'elevated to this position after having enjoyed a thoroughly European upbringing,' Snouck Hurgronje lost no opportunity in writing to Van Heutsz in October 1905 (SH to VH 27-10-1905, Gobée and Adriaanse 1957-1965:538). In 1924 he became Regent of Batavia and, at the end of 1929, a Member of the Council of the Indies. On the 
recommendation of Snouck Hurgronje, Hoesein Djajadiningrat would go on to study Oriental languages in Leiden in 1905. In 1913 he became the first Indonesian to defend a PhD thesis (Djajadiningrat 1913). He passed with credit. In 1920 he was appointed Adjunct Advisor of Native Affairs. In 1924 he became a professor at the Law School in Batavia, and from 1935 to 1939 he was a Member of the Council of the Indies

Two other priyayi sons destined for a high position in the native administration in whom Snouck Hurgronje took an active interest at the end of the nineteenth century were Koesoemo Oetojo and Wiranatakoesoema. Koesoemo Oetojo would become Regent of Ngawi from 1902 to 1905 and thereafter of Japara to 1926. It is interesting that Achmad Djajadiningrat (1936:267) wrote about him: 'Koesoemo Oetojo had a difficult youth, as I had', giving us some insight into how such boys experienced their fate. Wiranatakoesoema, whom Snouck Hurgronje significantly transferred from the OSVIA in Bandung to a European secondary school in Batavia, did not finish his European secondary education, but nevertheless became Regent of Cianjur in 1912 and of Bandung in 1920 (Sutherland 1979:49, Van Neil 1984:48).

Snouck Hurgronje's involvement in the upbringing of the sons of the traditional Indonesian elite should really be seen in the form of a project. 'This involvement cost a great deal of time: I had to keep in touch with the parents by an exchange of letters or have them lodge with me in my house; to find a decent home for young men who received their education under my supervision, I had to look for suitable European families and also had to remain in touch with them; I also had to be acquainted with the teachers of the young men and they themselves of course had to be able to consider my house a place of refuge when they were confronted with problems. Only frequent visits created the prospect of intimate contact and a solid assessment' ( $\mathrm{SH}$ to VH 19-8-1905, Gobée and Adriaanse 1957-1965:559-60)

Snouck Hurgronje intervened in matters concerning the selection of a school and the search for a suitable boarding house. As late as 1911 he complained that the fruits of Western education were often spoiled by the environment in which the boys spent their time outside schoolhours, which was 'detrimental rather than beneficial' to their education. For the time being, they had to lodge with European, that is thoroughbred European, families (Snouck Hurgronje 1915:92). An example he gave in a letter to Rooseboom is cogent. It concerned a 'young native man of good 
birth' in his care for whom somebody else had found a boarding house at a time when Snouck Hurgronje himself had been absent for a longer period of time. The boy in question had been accomodated with an IndoEuropean family. He had not liked it and had asked Snouck Hurgronje to find him a new home with a better family. He had had no complaints about the food and the accommodation, but had found the atmosphere in the house vulgar. One son, studying to become a civil servant, usually quarrelled with another son 'who lived partly as a Native', about native women. Furthermore, the Dutch the members of the family spoke was far from perfect. Eventually Snouck Hurgronje's protégé graduated from the HBS and stood 'morally and intellectually far above the whole environment from which I rescued him' (SH to R 8-9-1904, Gobée and Adriaanse 1957-1965:543-4).

The young men selected by Snouck Hurgronje frequently came to his house where they had the opportunity to meet like-minded students as well as leading Islamic scholars, intellectuals and administrators who were part of Snouck Hurgronje's network (Van Niel 1984:48, Laffan 2003:91). ${ }^{4}$ This was indicative of the role Snouck Hurgronje had assigned himself. He saw himself as a surrogate father and kept a close watch over the boys while they were living in Batavia. Indeed, writing about his relationship with one of his protégées, Raden Suria Nata Pamekas, the son the former Patih of Sukabumi, he remarked that for years he had taken the place of the boy's father (SH to DCA 17-8-1905, Gobée and Adriaanse 1957-1965:532). Snouck Hurgronje took good care of the boys whose education he supervised. He arranged extra tutoring when this was necessary, gave them presents when they passed exams and cared for them when they were ill. His concern was not limited to the intellectual development of his pupils, he also worried about their moral education and health, Achmad Djajadiningrat (1927:66) would later write. Achmad Djajadiningrat was impressed by such care, but Snouck Hurgronje (1908: 163) gave a less altruistic reason for his solicitude (something of which Achmad Djajadiningrat was well aware). He was afraid that were Achmad Djajadiningrat to fall ill, other Indonesians might interpret this as a sign from God that He opposed European education for Indonesians.

His influence did not stop after his protégés had finished their education. By acting as he did, Snouck Hurgronje built a special relationship with at least a number of the boys in his care. The young priyayi stayed in touch with him. In his letter to Governor-General Rooseboom in September 
1904, Snouck Hurgronje wrote that time and time again he received proof that such young, Western-educated native civil servants continued their studies and complained - but is it really a complaint? - that he found that this took up a large amount of his time (SH to R 8-9-1904, Gobée and Adriaanse 1957-1965:538).

Snouck Hurgronje was pleased with the results. In general, the 'younger Native civil servants' who had completed this education had a higher intellectual standard than the average European civil servant and were keen to improve themselves even further, he wrote to Rooseboom in 1904 (SH to R 8-9-1904, Gobée and Adriaanse 1957-1965:538).

\section{Submerged in a European environment}

What Snouck Hurgronje wrote about the efforts made by himself and like-minded Dutch people in Java to mould young Indonesians of noble descent leaves no doubt he considered the Indonesian way of life a corrupting influence, antagonistic to the ideal society, the 'unity of culture', of which he dreamt. One essential part of his concept seems to have been that promising Indonesian boys should be removed from their own background and placed in European families. He wrote explicitly about the success of sending Indonesians to Dutch secondary schools coupled with their education in European families (Italics mine, Snouck Hurgronje to Van Heutsz 13-12-1905, Gobée and Adriaanse 1957-1965:504). He was even more outspoken in a letter to the Director of Civil Administration of 22 August 1904. He lauded himself for his 'unrelenting involvement' which, the reader cannot but conclude, had achieved the result that finally and for the first time Banten had a regent and a number of young priyayi who were properly educated. A similar remark was made in a letter to Van Heutsz in August 1905 in which he writes that for sixteen years he had 'incessantly striven for the raising of the moral and intellectual upbringing of the sons of Native civil servants' (SH to VH 19-8-1905, Gobée and Adriaanse 1957-1965:556-7).

The traditional methods of upbringing and ways of life found no favour in his eyes. In fact, Snouck Hurgronje is extremely scathing about them. He contrasts his achievement in Banten with the situation in Bandung and Garut. In Bandung, the Dutch colonial civil servants had allowed the Regent to 'make a mess of' the education of his sons. In Garut the story had been much the same. There the sons of the Regents grew up 
'incompetent idlers, gamblers, womanizers and anything else which could be thought of.' As in many other instances Dutch civil servants had not intervened. Everywhere one looked it was almost the same, Snouck Hurgronje lamented in his letter. (Gobée and Adriaanse 1957-1965:527). In another letter of 27 October 1905 to Governor-General Van Heutsz, he wrote about 'the tainted children (bedorven kinderen) of the priyayi in former days, contrasting their conduct with that of their 'modern educated' counterparts (Gobée and Adriaanse 1957-1965:538).

Raden Suria Nata Pamekas was one of this modern educated contingent. In his early youth he had enrolled at the local European school in Sukabumi and had conversed with his father in Dutch. When he was a little bit older, he had been sent to Batavia where he attended a private European school and the grammar school. In Batavia he had lived with a 'cultivated European family' (een beschaafde Europeesche familie). Typically, Snouck Hurgronje noted that Raden Suria Nata Pamekas had 'pretty much escaped the disadvantages of a Native education.' (Snouck Hurgronje to Director of Civil Administration 17-8-1905, Gobée and Adriaanse 1957-1965:532). Needless to say, Suria Nata Pamekas 'combined intelligence with sound judgment, great diligence, sense of duty and honesty' (SHurgronje to DCA 17-8-1905, Gobée and Adriaanse 1957-1965:532).

Paying heed to Snouck Hurgronje's endeavours, priyayi families also began to raise their children in a different, more Westernized, way in the private sphere of their own homes. In his letter to Rooseboom of 8 September 1904, Snouck Hurgronje noted that he knew of two prominent regent families - we may guess those of Ahmad Djajadiningrat and of Koesoemo Oetojo - who raised their children in a European fashion. The mothers were not indolent and incompetent; the fathers paid attention to the upbringing if their children (and were monogamous). The results of such an upbringing are palpable, he wrote (SH to R 9-9-1904, Gobée and Adriaanse 1957-1965:544-5). ${ }^{5}$ In fact, Snouck Hurgronje even had had an active hand in the emergence of such families, extending his care to the education of priyayi daughters. In the wake of the sons, daughters of the priyayi class were sent to European schools. They had also been illegible for Western education. Though he was not one-hundred-per cent sure, Achmad Djajadiningrat (1936:83) assumed that, at the suggestion of his father, Snouck Hurgronje arranged for the European education of two daughters of the Regent of Galuh in a convent in Batavia. His father would have realized that Western-educated boys would prefer 
Western-educated girls as their spouses. One of the two girls, Raden Ajeng Lenggang Kantjana, became Achmad's wife; the other married his brother Moehamad.

In general, however, Snouck Hurgronje seemed less satisfied about what a European education of Javanese girls accomplished than about the influence it had had on young men. In 1911, he observed that there had been a number of 'girls from prominent Native families' who had attended European schools, but that generally the European social manners they had acquired was not much more than a veneer. These girls left school too early and not enough attention was paid to the building of their character. They had not become 'worthy life partners' (waardige levensgezellinnen) who could assist their husbands in associating native families with what was the norm in the West (which he considered essential to the success of such a transformation). It will not come as a surprise that he identified the lack of supervision by 'sound European women' (degelijke Europeesche vrouwen) as the reason for this. In an effort to change matters, Snouck Hurgronje challenged the missionary societies. He suggested that turning Indonesian families into their Western equivalents was such a glorious task that he wondered if female missionaries should not become involved. By doing so, they would contribute to the 'political-national association', whereas concentrating on untimely efforts at conversion - which in all probability would fail and might even lead to social unrest - might be harmful to this goal. Those who aimed at the Christianization of the Netherlands Indies should consider what Snouck Hurgronje in this instance even called 'political-national annexation', the first step towards their ideal, and should contribute to this wholeheartedly. (Snouck Hurgronje 1915:93-4).

\section{Aceh}

In April 1898 Snouck Hurgronje was put firmly in charge of the nonmilitary aspects of the subjugation of Aceh. Turning to the impressionable younger generation and Westernizing them was once again one of the keystones of his plans to develop Aceh and eventually turn the region into one loyal to Dutch rule. His friend and another of his devoted admirers, Van der Maaten (1948:2004), observed that Snouck Hurgronje's aim was to be involved in 'an unremitting benevolent involvement of the Administration in the bringing up and education of young, notable Acehnese.' What Snouck Hurgronje wanted was a serious effort to be 
made to educate the sons of the local heads (Van der Maaten 1948: 154). As time passed, Dutch military successes raised his optimism. Early in the 1890s, writing about their 'naive self-satisfaction', Snouck Hurgronje (1893-1895 I:173) in De Atjèhers had still observed that the Acehnese did not show much inclination to learn from the infidels. By the end of the century he was full of optimism. Large-scale military expeditions seemed a thing of the past, though it still might take considerable time before Aceh was a region basking in peace and prosperity. The results of the 'taming process' (temmingsproces) were surprising: 'Sons of half-wild, opium-addicted heads go to school on a regular basis in large numbers (some go there from their distant kampungs by velocipède!) and behave like ordinary people' (SH to N 13-4-1900, Van Koningsveld 1985b:80).

His conflict with Van Heutsz during 1903 and 1904 meant that Snouck Hurgronje had to distance himself too early from Aceh to be able to put his ideas into practice there. Turning away from Aceh meant that he left the development of the region and its inhabitants, including their intellectual education, to others. He could still continue his efforts in Java, especially West Java, where he had already been engaged in the education of number of priyayi sons in the past and where he would spend his remaining days in the Netherlands Indies.

\section{The native civil service}

Back in Java Snouck Hurgronje continued with his 'experiment', adding an extra dimension to it. Having succeeded in educating a number of talented priyayi sons, he began to propagate the empowerment of the native civil servant corps and foresaw the eventual abolition of such positions as Resident and Assistant-Resident in the Dutch civil service in the colony whose main task was to supervise and guide their Indonesian counterparts such as the Regents (Bupati) and District Chiefs (Wedana). Significantly, his first letter to Rooseboom, in which he expounded this idea of removing the Dutch tutelage (ontvoogding) of Indonesian civil servants in detail, dates from 8 September 1904. In European circles the suggestion that at some time in the future governance of local society should be left to Indonesian civil servants and that the parallel supervising European administration would no longer be needed was even more detested than the idea of allowing Indonesians to enrol at European schools. The Dutch policy makers in the Department of Civil Administration and following 
their example probably many of the Europeans living in the Netherlands Indies were appalled by such a suggestion (Gobée and Adriaanse 19571965:xvi).

The germ of his plan was his success in providing people like Achmad Djajadiningrat and Suria Nata Pamekas with a sound education. After the turn of the century, the prospects of Western education for future Indonesian civil servants seemed more promising than they had been even a few years earlier. It was a time when increasing numbers of Indonesians were adopting aspects of a Western way of life, which had been the preserve of members of the Indonesian aristocracy for a long time. More people began to wear Western attire and Western furniture made its appearance in more houses and offices. It was a development which would touch a variety of social groups, most of which did not enter into Snouck Hurgronje's plans. He remained focused on the elite.

What he observed probably even actually worried him and might have motivated him to keep an extra vigilant eye on the education of the priyayi sons. He had already expressed his concern in 1893, which is surprisingly early. Snouck Hurgronje had taken Achmad Djajadiningrat under his aegis in 1890. Only three years later he confessed to Nöldeke that he doubted whether the increase in European-educated civil servants in the native administration would contribute to the well-being of the Indonesian population and the strengthening of Dutch authority. Though at that time such persons were probably few and far between, in his letter Snouck Hurgronje used such expressions as 'the floodgates have been opened' and observed that 'the Europe-craving (Europazucht) has become an endemic, ineradicable illness'. Revealing some disquiet, he continued by writing that the most difficult question which had to be answered in view of this development was how to avert its unwelcome consequences. (SH to N 4-61893, Van Koningsveld 1985b). One solution he might have envisaged was to keep a close watch on the bright boys among the Javanese traditional elite, who might hold key positions in the native administration in later life. Certainly they should be the pioneers of a new type of Javanese civil servant, but they should also be deeply entrenched in the culture and views of the colonial overlord and immune to the negative consequences which Snouck Hurgronje feared lay in store. One additional advantage was that such boys had also been removed from an environment which, as in the case of Wiranatakoesoema, had been anti-Dutch (Sutherland 1979:50). Indeed, initially at least Indonesian students in European secondary 
schools seemed insulated from the propaganda of the early Indonesian nationalists. They were not targeted by them as students of OSVIA were. In 1908, the founding fathers of Boedi Oetomo would turn to students of Indonesian institutions of secondary education to expand their ranks. They did not bother with the European schools, where the number of Indonesians was negligible (Djojohadikusumo 1969:30).

The demand for Western education was indeed expanding. Ahmad Djajadiningrat's success meant that other priyayi fathers turned to him and other Europeans for advice and mediation in the education of their sons (Djajadiningrat 1927:66). They did so, Snouck Hurgronje would later write, with 'almost movingly trust' (Snouck Hurgronje 1915:7980). ${ }^{6}$ 'Lately, more than in the past, the Natives, especially those of rank, had been trying to work their way up leaving moral and intellectual backwardness behind them with the encouragement of the government,' Snouck Hurgronje wrote in September 1903 to the Director of Civil Administration. In the same letter, he pointed out that 'with regard to the whole upbringing of their children', not just the selection of schools, the parents willingly follow the advice of Europeans whom they trust; and in saying so, he might have had himself first and foremost in mind. The parents made great sacrifices (Gobée and Adriaanse 1957-1965:501). They also did so in a material sense and were sometimes prepared to spend 25 to 35 per cent of their income on the education of their children (Djajadiningrat 1936:352). In 1904 Snouck Hurgronje again observed that 'in the upper classes among the Natives' more and more parents were prepared to make sacrifices to give their sons the best possible education (SH to R 5-7-1904 Gobée and Adriaanse 1957-1965:501). The following year he touched upon the subject in more general terms: an increasing number of Native people aspire to the advantages of an upbringing and education which will raise them in every respect to the highest level of European civilization' (SH to VH 19-2-1905, Gobée and Adriaanse 19571965:553-4).

In his letters and recommendations about the education of Indonesians, Snouck Hurgronje remains silent about the Arab community. Nevertheless, in 1897 he had been approach by a rich Arab, a descendant of the Prophet Muhammad, who contacted him to inquire about a European primary and secondary education for his ten-year-old son, whom he had brought especially from the Hadramaut (Yemen) to Batavia for this very purpose. This case provided Snouck Hurgronje with a unique opportunity. Arabs 
living in the Netherlands Indies usually sent their sons to the Hadramaut for their education (Kaptein 2009:34). However, instead of hastening to include Arabs in his project, he reacted lukewarmly, becoming more excited about what he might learn from the boy about the Hadramaut than about the latter's education. (SH to N 24-12-1897, Van Koningsveld 1985b:61-2). He might have reacted differently in later years when he and other Dutch people reacted vehemently to young Indonesian men, mostly if not exclusively of Arab descent, who would turn to the Ottoman Empire for their education in 1898 and subsequent years. Concerned Dutchmen were sure that this was a sure sign that they preferred Islamic culture to its Western counterpart. Fear reigned that it was that not only their religious and cultural affiliations which were being called into question, but also their political loyalties. (Van Dijk 2002:67-70)

\section{Modern Islamic education makes its appearance}

Good modern education was an issue not confined to the social and political elite and the secular sphere; it was also heatedly discussed in the devout Islamic community. Alongside the pesantren, the traditional boarding schools at which only religious education was provided following an age-old system of instruction, madrasah began to be established. In pesantren the students usually sat in a circle on the floor around their teacher; although some did also receive individual instruction. Pertinently, there was no fixed curriculum or assessment system. Western methods of education were introduced in madrasah. These educational institutions had classrooms, blackboards, chalk, chairs and desks, a system of school classes, a fixed curriculum, and certificates (See for instance Rosidin 2007:38-41). In the very first years in which this development took shape, it was the copying of the teaching methods of Western institutions of education was often adopted first. The teaching of such secular subjects as arithmetic, geography and languages usually followed a few years later.

It cannot be established with any certainty that Snuck Hurgronje was very aware of this trend. The first such modern Islamic school was set up in July 1905, less than a year before he left the Netherlands Indies in March 1906. ${ }^{7}$ It was the Manba' al-'Ulum school established on the initiative of Susuhunan Pakubuwono X of Surakarta. It was founded in a milieu with which Snouck Hurgronje was very familiar. The school was closely linked to the penghulu office and the penghulu environment (Hisyam 2001:1405). In hindsight, it is not so surprising that penghulu played such a pivotal 
role in the establishment of the Manba' al-'Ulum school. Penghulu were as much part of the world of the colonizer as that of the Islamic and Javanese community. They operated in an environment on which Western ideas had already left their mark, and in which at that time, as Ricklefs (2007:212) has pointed out, members of the Javanese aristocracy 'embraced European learning and life styles with enthusiasm.' Other Islamic leaders operating outside the official religious administration and remaining independent of it followed suit. The famous Tebuireng pesantren of the Nahdlatul Ulama, founded by KH Hasjim Asja'ri in 1899, established a madrasah in 1916. Initially, only religious subjects were taught there, but within a few years this had changed. In 1919 classes in Malay, arithmatic and geography were introduced (Dhofier 1982:104).

\section{Islam}

Snouck Hurgronje might not have paid much attention to this trend. Those whom he first and foremost, perhaps exclusively, had in mind were the members the Javanese elite. In 1911 in his lecture in The Hague his main argument in favour of his association concept was the extraordinarily great 'desire of the higher classes in Java to cultivate present-day civilization wholeheartedly' (Snouck Hurgronje 1915:79-80). He might even have frowned on the intention of Muslims to develop their own educational system. In 1911 he observed with satisfaction that even Islamic clerics were tending to send their sons to a European school, and not to a pesantren, in increasing numbers, making no mention of new developments in Islamic education in the colony (Snouck Hurgronje 1915:87).

One of his intentions was to make the sons of the Javanese elite, pupils who would be immune to the preaching of what he considered narrowminded Islamic leaders. In the Netherlands Indies the spirit in 'pious' Muslim circles was 'very narrow, he wrote to Goldziher (SH to G 1-61893, Van Koningsveld 1985a:140). His focus was on full secular European education for the sons of the Indonesian elite and he was sure that this was also what their fathers wanted. This sort of education coupled with sound guidance by Europeans mentors should produce a new Indonesian elite, with its roots in its traditional secular sphere. It would shield it members from the influence of the devout Islamic community. Again, he voiced this opinion for the first time at a strikingly early moment, in 1893, when his first protégé, Achmad Djajadiningrat, enrolled in the HBS. The young men he had taken under his tutelage remained Muslims, 'but their intellectual 
current is moving very far away from the mass of the humble, tillers of the soil and from the cultivated, but cultivated in a narrow sense, leaders of religious life.' The latter, he went on, 'from self-interest or inner conviction propagandize their mode of thought, but the Europeanized Natives have no desire at all for propaganda, and prefer to maintain a philosophical silence towards the words of the fellow members of their race' ( $\mathrm{SH}$ to $\mathrm{N}$ 4-6-1893, Van Koningsveld 1985b:35).

What Snouck Hurgronje envisaged were Westernized Muslims. In his lectures at the Netherlands-Indies Civil Servants College in The Hague, he spoke about a unity of culture which would make the differences in religion between the Dutch and Indonesians politically and socially irrelevant. Snouck Hurgronje, himself the son of a clergyman, admitted that the perfect form of cultural unity should include unity of religion. He praised the missionaries, who also had such a form of assimilation in mind, but realized that it was unrealistic to expect that they would succeed in their aim (Snouck Hurgronje 1915:84-5). He could believe in his own concept of association because he adopted a very Western concept of religion as his point of departure. It was a way of thinking which acknowledges a separation between the religious and secular spheres of life. His words imply that at a certain point in future he expected that Muslims would view their religion the way Christians did. To many Muslims, not only those whom he branded as narrow-minded, such an approach was anathema in Islam. Their Islam was not confined to the sphere of religion proper, it also permeated social and political life. How far this should go is open to debate among Muslims. At certain moments in history they might with varying degrees of intensity differ in opinion about the implications and the extent to which the secular and the religious can and should be separated. It is a discussion which influences the degree to which individual Muslims are prepared to accept aspects of Western life, but the fact remains that, even at the time Snouck Hurgronje developed his association idea, there was a fundamental difference between the way Christians and Muslims, or at least some of them, thought about the implications of the prescripts of their religion for society. A section of Indonesian Islamic society might have been receptive to his suggestions; other Muslims were downright hostile to it, not least because of the connection they made between the West and Christianity.

Snouck Hurgronje's line of reasoning and what it implies is best encapsulated in the qualification he gives of the Acehnese in one of 
his letters to Goldziher: ' Religiously viewed the Acehnese are very poor Muslims: addicted to the use of opium, riven by age-old tribal feuds as are the Bedouins, untrustworthy to each other and to strangers etc. Politically it is another story: the hatred of kaffirs and the most fatuous self-conceit permeates the flesh and blood of these people' (italics his, SH to G 2-111891, Van Koningsveld 1985a:131). De Atjèhers abounds with many similar qualifications: 'The real Acehnese, as far as he does not neglect his religion completely, actually participates with more zeal in the religious or quasi-religious meetings in the meunasah [village house for men] than in the gatherings in the mosque, where he does not feel completely at ease. He loves to give kanduri (religious meals) and visit them; during ratib [zikir] ....he can work himself up to fever pitch; the ritual practices prescribed by the law do not interest him.' (Snouck Hurgronje 1893-1895 I:90). He might have been right, but how he knew we are ignorant, because in the course of the preparation of his book, he never attended any such occasions. During the time he spent in Banda Aceh in 1891-1892, he did not venture out of the tiny enclave which was then under Dutch control. Most, if not all, his information came from hearsay.

Such statements may have been inspired by his loathing of tarekat, Islamic mystical brotherhoods. They are also an indication of how much Snouck Hurgronje identified Islam, or religion, with formal orthodoxy, with a compliance with its basic tenets. Such an approach and the distinction Snouck Hurgronje made between religious and political aspects are essential to his association idea and the way he wanted to deal with Islam. In another lecture at the Netherlands-Indies Civil Servants College, he expounded the foundations of a Dutch Islam policy. It should steer away from the dogma of the faith (which posed no threat to the State) and those activities which Muslims considered belonged to their religion in a narrow sense, but should act against all that was of a political nature. In his reference to the latter, he included everything which formed a danger to Dutch rule. He explained to his audience that the words khalifat, PanIslamism, and holy war more or less summed up what he had in mind (Snouck Hurgronje 1915:54-5,67). It was sound colonial advice, but built on quicksand as it was based on a Western dichotomy, which is not so clear-cut in the eyes of Muslims.

These examples show that Snouck Hurgronje had very trenchant ideas about religiosity and religious identity. What he identified as religion was an orthodox dogmatic adherence to the faith. Faithfully complying to the 
basic ritual commands of Islam and refraining from immoral conduct was what made somebody a good, devout Muslim his eyes. What fell outside this sphere, especially anything he did not like, belonged to the field of politics and could be suppressed by the colonial authorities, and in certain circumstances there was indeed no other option.

\section{Conclusion}

I began by stating that Snouck Hurgronje appears to have been a bundle of contradictions. He wrote about association, about 'enough unity of culture ... to erase the political and social significance of the difference in religious profession' and observed with apparent delight that his priyayi were immune to the religious propaganda of the local Islamic leaders. His interpretation of the term religion was restricted as indeed was the way in which he used the words civilized and civilization. The people who should lead the way towards association formed one section of a very small elite, both in the Netherlands Indies and in Holland. With his highly developed sense of class-consciousness, Snouck Hurgronje left no doubt about the fact that when he spoke or wrote about civilized Europeans, he had a particular group of people in mind. In one of his lectures in The Hague, he pointed out to his audience that the Indonesian students in the Netherlands were 'infinitely much closer' to him and them than were entire classes of their own Dutch society (Snouck Hurgronje 1915:101). Restrictive as Snouck Hurgronje's approach was, advocating the opening up of Western education to only a small elite group, it is not surprising that soon good education open to all Indonesians ranked as one of the demands of the early nationalist movement.

In the end, we have to ask did Snouck Hurgronje himself believe in his association concept? I venture to suggest that the answer is yes, but only when assimilation occurred under close supervision. When members of the Indonesian secular elite adopted a Western way of life under careful guidance, there was nothing the matter. Snouck Hurgronje's reaction was different when Muslims acted of their own accord. At the time at which he was actively involved in the education of priyayi, sons he harboured doubts about Muslims in their present condition propagating change. Algerian attempts to present European culture as a model to be followed he dismissed as 'hypocrisy in good faith' (SH to N 27-5-1902, 
Van Koningsveld 1985b:95). He might of course have changed his mind later, nevertheless the impression remains that steps towards association initiated by Islamic leaders, by 'the "civilized" Muslims, who eat with forks, don a tie, shirt and laced boots and reform Islam in the company of their European friends,' as he himself described them, did not win his sympathy (Snouck Hurgronje 1886: 291). He far preferred his friend Sajjid Oesman, whom he typified as a very conservative Muslim - he 'grows very annoyed when the beautiful native maidens expose themselves to everybody's eye unveiled, even with bare heads!' as Snouck Hurgronje characterized him in a letter to Goldziher - but at the same time he was a tolerant member of his faith. Sajjid Oesman would never take such a course. He would show that the good elements in European civilization were present in Islam and propagated an Islam 'civilized kafirs can stomach' (SH to N 27-5-1902, Van Koningsveld 1985b:95), SH to G 28-1-1894, Van Koningsveld 1985a:144-5). Elsewhere Snouck Hurgronje was rather dismissive of the men with 'their Frankish trousers and their fezzes', who propagated modernist Islamic ideas in the capitals of the Islamic countries (Snouck Hurgronje 1898:320). He was positive their efforts were bound to fail. Their ideas could not count on winning enough sympathy among the influential ulama and the ordinary people ever to become successful (Snouck Hurgronje 1898:320-1).

As already mentioned, Snouck Hurgronje began his project to halt what he saw as undesired consequences which might possibly materialize from a Europe-craving among Indonesians. His belittling of some of the outward manifestations of assimilation or acculturation by Muslims raises questions about whether deep down Snouck Hurgronje could not be counted among those Europeans in Asia who felt uncomfortable with Indonesians or Indians adopting aspects of Western culture. Could only a small select group of priyayi boys be allowed to dress and act in a Western way and emerge from this sincere?

As Brugman (1989: 91-2) has pointed out, Snouck Hurgronje sorely underestimated the forces of change in Muslims society around the turn of the nineteenth century. Initially he even appears to have ignored obvious trends to the contrary in the Middle East and have identified Muslim society with what we nowadays call its traditional image, the world of the old-fashioned ulama. In one of his 1911 lectures, he admitted that progress had been made in the Middle East, but continued to see Islam as an obstacle to much-needed reforms. He captured what he considered 
the essence of his approach in the phrase that ' $[\mathrm{u}]$ pbringing and education can emancipate Muslims from the Islamic system' (Snouck Hurgronje 1915:79). It is a sentence which summarizes the basic idea underlying his association policy, reflecting his experience with the Western education of priyayi sons.

Reading such a sentence begs another question. At that moment when Snouck Hurgronje rated the chance of success of modernization in the Middle East so low, how could he have been so sure that association could succeed in Java and elsewhere in the Netherlands Indies? His plans rested on the co-operation of a semi-secularized elite group. Was he convinced that Islam in the Netherlands Indies could somehow be neutralized? In fact, he considered Islam less of an obstacle in the Netherlands Indies than in the Middle East. The arguments he advanced are not strong: the relatively short presence of Islam in Java had left many elements of life untouched; the many contacts the Javanese had in the past with other cultures; and above all - but he could not have been blind to the evidence to the contrary - their obedience to their superiors and the willingness of the latter to follow the directives of Dutch civil servants (Snouck Hurgronje 1915:79).

In spite of his initial doubts, Snouck Hurgronje eventually saw international developments as proof that he might be right. In 1914, during a lecture tour in the United Stated, he expressed himself much more positively than he had done in 1911 in The Hague. Finally he praised the modernist effort and showed himself confident about the possibility of reform, even in the Middle East (Snouck Hurgronje 1916:141-5). It might have made him more optimistic, but it does not distract from the fact that when he took charge of the education of priyayi boys as well as when he formulated his association idea publicly, he had still thought differently. 


\author{
Abbreviations \\ DCA Director of Civil Administration \\ G \\ I. Goldziher \\ N Th. Nöldeke \\ R W. Rooseboom \\ SH C. Snouck Hurgronje \\ VH J.B. Van Heutsz
}

\title{
Endnotes
}

1. See the review by James Scott of Empires of Intelligence: security services and colonial disorder after 1914 by Martin Thomas in the London Review of Books, Vo. 30, no.19, 9 October 2008 (p.28) in which he writes that the 'colonies, beginning with Ireland, could be viewed as a vast experimental terrain where all kinds of unproven techniques and procedures could be tested. As guinea pigs, colonial subjects were ideal. They could be mobilized for experiments against their will; if the experiment went badly for them they had no representative institutions through which to cry foul.'

2. Snouck Hurgronje considered his 'experiment' with $\mathrm{N}$, who had wanted to study medicine but had had to enter the training for civil servants for financial reasons, a failure. He wrote that $\mathrm{N}$ suffered from a lack of energy and was of average ability, not suited to become a senior native civil servant. (SH to VH 19-2-1905, Gobée and Adriaanse 19571965:555).

3. Hoesein was spotted as a bright boy who should go to a European school by an army sergeant, the commander of a detachment of the Armed Police in Menes, Ruselar, who taught him Dutch. In 1893 he entered the European Primary School in Serang. In 1904 Hoesein graduated from the HBS as first in his class. Another brother, Moehamad, was sent to the OSVIA in Bandung in 1893 by his father.

4. Djajadiningrat (1936:77-8) mentioned people like Sajjid Oesman, Honorary Advisor on Arabic Affairs, (who always spoke Arabic with Snouck Hurgronje, making it impossible for him to understand what they were talking about) and Hasan Moestapa, who at Snouck Hurgronje's instigation had been appointed Chief Penghulu of Banda Aceh for three years in 1893 . He also noted that Chinese never visited Snouck Hurgronje.

5. In another letter, Snouck Hurgronje praised the Regents of Ngawi, Serang and Demak, and somewhat more moderately those of Panarukan and Mojokerto. Other successful protégées he mentioned were Suria Nata Pamekas and 'the Malay Salim,' that is Haji Agoes Salim, who was to become one of the most prominent Islamic and national leaders in Indonesia (SH to VH 19-8-1905, Gobée and Adriaanse 1957-1965:556, 560).

6. Among Indonesians a different story did the rounds. In Soeloeh Rajat Indonesia of 19 December 1928 (Vo. 2, nr 51, p 563), there is a report that it was common practice for Regents to be successful in having their own sons or those of relatives and friends enter 
European schools by resorting to surreptitious practices. Among these were giving such children Dutch names (the story of Achmad Djajadiningrat must have made an impression) and giving presents to teachers to have the children admitted as students. Soeloeh Rajat Indonesia was published by the Indonesische Studieclub of Soetomo in Surabaya.

7. Djajadiningrat (1936:261) noted that after Snouck Hurgronje had left the Netherlands Indies his involvement in the education of Indonesian boys destined for a career in the native civil service was continued in a 'commendably ' by his successor G.A.J. Hazeu (See also Laffan 2003:95) One of the persons whose care was taken over from Snouck Hurgronje by Hazeu was Wiranatakoesoema (Sutherland 1979:50). It may have been a sign of changing times that Hazeu’s best-known protégé was Alimin Prawirodirdjo. Hazeu had taken him under his tutelage when he was nine years old (Tichelman 1985:668). Alimin would not become a respected civil servant or scholar, but a prominent leader of the Indonesian Communist Party (PKI).

\section{Bibliography}

Brugman, J.

1989 Snouck Hurgronje's study of Islamic law, in W. Otterspeer (ed.), Leiden Oriental Collections 1850-1940, pp. 82-93. Leiden: E.J. Brill/Universitaire Pers Leiden.

Calcar, R.P. van

1936 DE MEESTER. Herinneringen aan Prof. Dr. C. Snouck Hurgronje 1857 1936. S.l.: s.n.

Dhofier, Zamakhsyari

1982 Tradisi Pesantren. Studi tentang Pandangan Hidup Kyai. Jakarta: LP3ES.

Dijk, C (Kees) van

2002 Colonial fears, 1890-1918. Pan-Islamism and the Germano-Indian plot, in: Huub de Jonge and Nico Kaptein (eds), Transcending borders, Arabs, politics, trade and Islam in Southeast Asia, Leiden: KITLV Press, pp.53-89.

Djajadiningrat, Achmad

1927 Een stuk van den arbeid van Prof. Snouck Hurgronje in het belang van de intellectuele ontwikkeling van het Indonesische volk, Djåwå, Vol. 7, pp. 65-7.

1936 Herinneringen van Pangeran Ario Achmad Djajadiningrat. AmsterdamBatavia: G. Kolff \& Co.

Djajadiningrat, Hoesein

1913 Critische beschouwing van de Sadjarah Bantăn: bijdrage ter kenschetsing van de Javaansche geschiedschrijving. Haarlem: Joh. Enschedé. 
Djojohadikusumo, Margono

1969 Herinneringen uit 3 tijdperken. Een geschreven familie-overlevering. Djakarta: Boekhandel Indira.

Gobée, E. en C. Adriaanse

1957-1965 Ambtelijke adviezen van C. Snouck Hurgronje 1889-1936. 3 Vol.. s-Gravenhage: Martinus Nijhoff. Rijks Geschiedkundige Publicatiën.

Hisyam, Muhamad

2001 Caught Between Three Fires. The Javanese Pangulu Under The Dutch Colonial Administration 1882-1942 (Leiden PhD dissertation).

Kaptein, Nico. J.G.

2009 Arabophobia and tarekat. How Sayyid 'Uthmān became advisor to the Netherlands colonial administration, in: Ahmed Ibrahim Abushouk and Hassan Ahmed Ibrahim (eds.), The Hadhrami diaspora in Southeast Asia. Identity maintenance or assimilation?, pp. 33-44. Leiden: Brill.

Koningsveld, P. Sj. van

1985a Scholarship and friendship in early Islamwissenschaft: the letters of C. Snouck Hurgronje to I. Goldziher from the Oriental Collection of the Library of the Hungarian Academy of Sciences, Budapest. Leiden: Rijksuniversiteit Leiden.

1985b Orientalism and Islam: the letters of C. Snouck Hurgronje to Th. Nöldeke from the Tübingen University Library. Leiden: Rijksuniversiteit Leiden.

Laffan, Michael Francis

2003 Islamic nationhood and colonial Indonesia. The umma below the winds. London and New York: Routledge Curzon.

Maaten, K. van der

1948 Snouck Hurgronje en de Atjeh Oorlog. Leiden: Oostersch Instituut.

Niel, Robert van

1984 (1960) The emergence of the modern Indonesian elite. Dordrecht/ Cinnaminson: Foris Publications. (Reprints on Indonesia)

Ricklefs, M.C.

2007 Polarising Javanese Society: Islamic and other visions (c. 1830-1930). Leiden: KITLV Press.

Rosidin, Didin Nurul

2007 From Kampung to Kota. A study of the Transformation of Mathla'ul Anwar, 1916-1998. Leiden: INIS/ Leiden University (PhD dissertation). 
Snouck Hurgronje, C.

1886 De Islam, Verspreide geschriften van C. Snouck Hurgronje I, pp 185-294.

1893-1895 De Atjèhers. 2 Vol. Batavia en Leiden: Landsdrukkerij en E.J. Brill.

1898 Le droit musulman, Verspreide geschriften van C. Snouck Hurgronje II, pp 285-326.

1908 De Inlandsche bestuursambtenaren, vooral op Java, Verspreide geschriften van C. Snouck Hurgronje IV (II), pp 147-68.

1915 Nederland en de ISLÂM. Leiden: E.J. Brill (2nd ed.)

1916 Mohammedanism. Lectures on Its Origin, Its Religious and Political Growth and Its Present State. New York: G.P. Putnam's Sons.

Sutherland, Heather

1979 The Making of a Bureaucratic Elite. The Colonial Transformation of the Javanese Priyayi. London etc.: Heinemann Educational Books.

Tichelman, F.

1985 Socialisme in Indonesië. De Indische Sociaal-Democratische Vereeniging, 1897-1917. Dordrecht and Cinnaminson: Fores Publications.

Wensinck, A.J. (ed.)

1923-1927 Verspreide geschriften van C. Snouck Hurgronje. Voorzien van een bibiographie en registers door A.J. Wensick. Bonn \& Leiden: Koert Schroeder \& E.J. Brill.

Kees van Dijk is Professor of the History of Islam in Indonesia at Leiden University and a researcher at the KITLV. 